\author{
SYLWIA ŁAZUK \\ Uniwersytet w Białymstoku \\ sylwia.lazuk@o2.pl
}

\title{
Rozwiązanie stosunku pracy bez wypowiedzenia z urzędnikiem służby cywilnej
}

\section{Termination of employment without notice with a civil servant official}

Streszczenie. Artykuł przedstawia rozwiązanie stosunku pracy bez wypowiedzenia z urzędnikiem służby cywilnej. W tym celu zostały ukazane regulacje związane $\mathrm{z}$ rozwiązaniem stosunku pracy bez wypowiedzenia $\mathrm{w}$ służbie cywilnej oraz przesłanki rozwiązania stosunku pracy z urzędnikiem służby cywilnej bez wypowiedzenia z jego winy. $Z$ dokonanej analizy wynika, że rozwiązanie stosunku pracy bez wypowiedzenia $z$ urzędnikiem służby cywilnej jest najbardziej niekorzystną formą rozwiązania stosunku pracy dla urzędnika i znacznie osłabia ochronę stosunku pracy.

Słowa kluczowe: rozwiązanie stosunku pracy bez wypowiedzenia; urzędnik służby cywilnej; przesłanki rozwiązania stosunku pracy bez wypowiedzenia.

Summary. The article presents the termination of employment without notice with a civil servant official. For this purpose, have been shown regulations related to the termination of the employment relationship without notice in the civil service and the grounds for the dismissal of a civil servant official without notice due to his fault. From the above analysis shows that the termination of employment without notice with a civil servant official is the most unfavourable form of termination of employment for an official and significantly weakens the protection of the employment relationship.

Keywords: termination of employment without notice; civil servant official; grounds for dismissal without notice.

\section{Uwagi ogólne}

Idei utworzenia korpusu służby cywilnej przyświecało stworzenie aparatu urzędniczego o charakterze względnie stałym, objętym ochroną przed nieuzasadnioną ważnymi względami utratą zatrudnienia w zawodzie. Powyższe założenie odnajdujemy także w wyroku Trybunału Konstytucyjnego z dnia 12 grudnia 2002 r. ${ }^{1}$, zgodnie z którym zatrudnienie w służbie cywilnej nie może być tylko przejściowym zajęciem, ale stałym źródłem utrzymania oraz miejscem pracy zapewniającym osobom kompetentnym możliwość realizacji kariery zawodowej. U podstaw takiego zapatrywania leży przekonanie o konieczności zapewnienia stabilności kadr w administracji publicznej tak, aby większość urzędników wykonywała ten

\footnotetext{
${ }^{1}$ K 9/02, OTK 2002, nr 7 poz. 94.
} 
zawód do emerytury. Wzmożona stabilizacja zatrudnienia, jako podstawowy instrument prawny wpływający na kształcenie i doskonalenie kadr, powinna objąć swoim zasięgiem te stanowiska pracy, gdzie rygory selekcyjne przy naborze na kandydatów są wysokie, a proces selekcji jest długotrwały i wymaga intensywnego przygotowania zawodowego. Trudno bowiem oczekiwać od pracownika, któremu nie zapewni się ochrony przed arbitralnym i nieuzasadnionym zwolnieniem z pracy, przede wszystkim w postaci gwarancji prawnych, że będzie on stale podwyższał swe umiejętności zawodowe.

W skład korpusu służby cywilnej wchodzą pracownicy i urzędnicy służby cywilnej zatrudnieni na stanowiskach urzędniczych w jednostkach organizacyjnych wskazanych w ustawie z dnia 21 listopada 2008 r. o służbie cywilnej ${ }^{2}$. Warto zaznaczyć, że podstawą zatrudnienia pracowników służby cywilnej jest umowa o pracę, zaś urzędników służby cywilnej - mianowanie. Wyodrębnienie z aparatu państwowego korpusu służby cywilnej odbywa się według dwóch kryteriów: rodzaju urzędu (jednostki organizacyjnej) oraz rodzaju zajmowanego stanowiska. W art. 2 u.s.c. wymieniono katalog osób, które są zatrudnione na stanowiskach urzędniczych w jednostkach organizacyjnych i są członkami korpusu służby cywilnej. Przykładowymi jednostkami są Kancelaria Prezesa Rady Ministrów, urzędy centralnych organów administracji rządowej, urzędy wojewódzkie czy komendy, inspektoraty i inne jednostki organizacyjne stanowiące aparat pomocniczy kierowników zespolonych list, inspekcji i straży wojewódzkich oraz kierowników powiatowych służb, inspekcji i straży. Od 1 stycznia 2016 r. katalog ten zostanie poszerzony o nową jednostkę: Biuro Krajowej Informacji Podatkowej ${ }^{3}$.

Osoby ubiegające się o przyjęcie do służby cywilnej powinny posiadać przede wszystkim zdolność pracowniczą, która warunkuje ważne nawiązanie każdego stosunku pracy. Oprócz tego, osoby ubiegające się o zatrudnienie w charakterze pracownika lub urzędnika służby cywilnej muszą spełniać szereg warunków kwalifikacyjnych określonych w ustawie o służbie cywilnej. Zgodnie z art. 4 u.s.c. w służbie cywilnej może być zatrudniona osoba, która:

1) jest obywatelem polskim,

2) korzysta z pełni praw publicznych,

3) nie była skazana prawomocnym wyrokiem za umyślne przestępstwo lub umyślne przestępstwo skarbowe,

4) posiada kwalifikacje wymagane na dane stanowisko pracy,

\footnotetext{
${ }^{2}$ Tekst jedn.: Dz.U. z 2014 r. poz. 1111 ze zm., dalej jako: „u.s.c.".

${ }^{3}$ Nowelizacja wprowadzona ustawą z 10 lipca 2015 r. o administracji podatkowej (Dz. U. z 2015 r., poz. 1269).
} 
5) cieszy się nieposzlakowaną opinią.

Oczywistym jest, że kryteria, stawiane kandydatom na urzędników służby cywilnej zatrudnionym na podstawie mianowania, są bardziej restrykcyjne i w tym wypadku znaczenie posiadają dodatkowe rygory, takie jak staż pracy czy znajomość języków obcych (art. 40 u.s.c.).

Jednym z zasadniczych elementów stabilizacji zatrudnienia urzędników służby cywilnej jest ustawowa konstrukcja ochrony przed rozwiązaniem stosunku pracy. Rozwiązania zawarte w tej ustawie w dużej mierze wzorowane są na regulacjach zawartych w ustawie o pracownikach urzędów państwowych - tzw. pragmatyce urzędniczej ${ }^{4}$.

Na potrzeby niniejszego opracowania skupię się na przedstawieniu regulacji z art. 71 ust. 3 i 4 u.s.c. O wadze tych unormowań świadczy to, iż stanowią jeden z najbardziej restrykcyjnych środków zwolnienia urzędnika z pracy. Stąd zasady korzystania z natychmiastowego sposobu rozwiązania stosunku pracy powinny być klarowne. Treść przesłanek, od których spełnienia uzależniono zastosowanie powyższego sposobu rozwiązania stosunku pracy, zawartych w ustawie o służbie cywilnej, nie spełnia tego wymogu. W związku z powyższym uzasadniona jest analiza obowiązującej regulacji oraz wskazanie wniosków de lege ferenda.

\section{Rozwiązanie stosunku pracy bez wypowiedzenia w służbie cywilnej}

Rozwiązanie stosunku pracy bez wypowiedzenia z mianowanym urzędnikiem służby cywilnej zostało uregulowane w art. 71 ust. 3 u.s.c.. Artykuł ten reguluje rozwiązanie stosunku pracy bez wypowiedzenia $\mathrm{z}$ przyczyn niezawinionych przez tego urzędnika $\mathrm{w}$ razie jego nieobecności $\mathrm{w}$ pracy $\mathrm{z}$ powodu choroby trwającej dłużej niż rok. Przepis ten ustanawia niejako swoistą ochronę pracownika przed niezwłocznym rozwiązaniem stosunku pracy przez jeden rok jego nieobecności w pracy z powodu choroby. Wydaje się, że roczny okres trwania choroby, powodujący nieobecność pracownika w pracy, jest wystarczająco długi, aby po jego upływie upoważnić pracodawcę do rozwiązania stosunku pracy bez wypowiedzenia. Ustawa o służbie cywilnej korzystniej niż kodeks pracy ustala maksymalny okres ochronny niezdolności do pracy z powodu choroby ${ }^{5}$. Jest to związane ze szczególnym statusem urzędników i ich wysokimi kwalifikacjami, podczas gdy regulacje kodeksowe mają charakter generalny i muszą odpowiadać szerokim potrzebom i oczekiwaniom partnerów społecznych,

\footnotetext{
${ }^{4}$ A. Dubowik, Nowelizacja ustawy o pracownikach urzędów państwowych, „Praca i Zabezpieczenie Społeczne" 1995, nr 8-9, s. 48.

${ }^{5}$ H. Szewczyk, Stosunki pracy w stużbie cywilnej, Warszawa 2010, s. 173.
} 
głównie pracodawców ${ }^{6}$. W świetle wyroku Sądu Apelacyjnego w Poznaniu z dnia 24 kwietnia 1996 r. ${ }^{7}$, niezdolność do pracy nie jest stanem, do którego można zastosować obiektywne kryteria; decydują bowiem o nim określony stan choroby, stopień jego nasilenia i charakter wykonywanej pracy.

Artykuł 71 ust. 4 u.s.c. stanowi, że w razie niezdolności do pracy z powodu choroby trwającej dłużej niż rok, urzędnik służby cywilnej zachowuje prawo do świadczeń pieniężnych tylko przez okres przewidziany w przepisach o świadczeniach pieniężnych z ubezpieczenia społecznego $\mathrm{w}$ razie choroby $\mathrm{i}$ macierzyństwa, co jest niewątpliwie niekorzystne dla urzędnika. Może on przebywać na zwolnieniu rok, nie narażając się na zwolnienie w trybie natychmiastowym, ale wynagrodzenie i zasiłek chorobowy będzie on otrzymywał zazwyczaj przez okres krótszy niż rok. Zgodnie z ustawą z dnia 25 czerwca 1999 r. o świadczeniach pieniężnych $\mathrm{z}$ ubezpieczenia społecznego $\mathrm{w}$ razie choroby $\mathrm{i}$ macierzyństwa ${ }^{8}$, zasiłek chorobowy przysługuje przez okres trwania niezdolności do pracy z powodu choroby lub niemożności wykonywania pracy z przyczyn określonych w art. 6 ust. 2 ustawy, jednak nie dłużej niż przez 182 dni, a jeżeli niezdolność do pracy spowodowana została gruźlicą lub w związku z ciążą - nie dłużej niż przez 270 dni (zgodnie z art. 8 ustawy). Warto również podkreślić, że nie wszystkim urzędnikom będzie przysługiwało prawo do świadczenia rehabilitacyjnego, które przysługuje przez okres niezbędny do przywrócenia zdolności do pracy, nie dłużej jednak niż przez 12 miesięcy. W świetle art. 18 wspomnianej ustawy, świadczenie to przysługuje po wyczerpaniu prawa do zasiłku chorobowego ubezpieczonemu, który nadal jest niezdolny do pracy, a dalsze leczenie lub rehabilitacja lecznicza rokują odzyskanie zdolności do pracy.

Podstawą rozwiązania stosunku pracy bez wypowiedzenia $\mathrm{z}$ mianowanym urzędnikiem służby cywilnej nie może być usprawiedliwiona nieobecność w pracy z przyczyn innych niż choroba przekraczająca okresy przewidziane w art. $53 \S 1$ pkt 2 i $\S 2$ kodeksu pracy $^{9}$, których upływ uprawnia pracodawcę do niezwłocznego rozwiązania umownego stosunku pracy z pracownikiem służby cywilnej. Niewątpliwie prowadzi to do wzmocnienia stabilizacji zatrudnienia urzędnika służby cywilnej ${ }^{10}$. Jednocześnie taka sytuacja różnicuje sytuację prawną urzędników i pracowników służby cywilnej, stanowiąc pewnego rodzaju niekonsekwencję ustawodawcy. Może to stanowić niebezpieczeństwo nadużycia takiego

\footnotetext{
${ }^{6}$ M. Mazuryk, w: W. Drobny, M. Mazuryk, P. Zuzankiewicz, Ustawa o stużbie cywilnej. Komentarz, Warszawa 2012 , s. 317.

${ }^{7}$ III AUr 42/96, „Prawo Pracy" 1997, nr 8, s. 42.

${ }^{8}$ Tekst jedn.: Dz.U. z 2014 r. poz. 159.

${ }^{9}$ Ustawa z dnia 26 czerwca 1974 r., tekst jedn.: Dz.U. z 2014 r. poz. 1502, dalej jako: „k.p.".

${ }^{10}$ H. Szewczyk, Stosunki pracy ..., s. 174.
} 
rozwiązania prawnego przez urzędników, którzy mogą korzystać z dłuższych nieobecności w pracy $\mathrm{z}$ innych przyczyn usprawiedliwionych niż choroba ${ }^{11}$. W stosunku do takiego pracownika nie jest nawet dozwolone wszczęcie postępowania dyscyplinarnego, gdyż z prawnego punktu widzenia każda jego nieobecność jest traktowana jako usprawiedliwiona.

Można zatem odnieść wrażenie, że ustawodawca przez przypadek pominął w art. 71 ust. 3 u.s.c. ten fragment przepisu, który dotyczy nieobecności w pracy urzędnika służby cywilnej $\mathrm{z}$ innych przyczyn niż choroba. Konieczna jest $\mathrm{w}$ tym zakresie ingerencja ustawodawcy, gdyż w aktualnym stanie prawnym nie ma możliwości niezwłocznego rozwiązania stosunku pracy z mianowanym urzędnikiem służby cywilnej z powodu jego nieobecności w pracy z innych przyczyn niż choroba ${ }^{12}$.

Ustawa o służbie cywilnej nie przewiduje trybu konsultacji związkowej w przypadku rozwiązania przez pracodawcę stosunku pracy bez wypowiedzenia $z$ mianowanym urzędnikiem służby cywilnej z przyczyny określonej w art. 71 ust. 3 u.s.c. Poza określeniem przyczyny uzasadniającej niezwłoczne rozwiązanie stosunku pracy z mianowania, w ustawie o służbie cywilnej nie uregulowano także innych kwestii. Wobec braku formy niezwłocznego rozwiązania stosuje się art. 30 §3 k.p., przewidujący wymóg zachowania formy pisemnej oświadczenia każdej ze stron o rozwiązaniu umowy o pracę ${ }^{13}$.

Zgodnie $\mathrm{z}$ art. 71 ust. 7 u.s.c., rozwiązanie stosunku pracy $\mathrm{z}$ urzędnikiem służby cywilnej bez wypowiedzenia z winy urzędnika może nastąpić w razie:

1) ciężkiego naruszenia przez urzędnika podstawowych obowiązków członka korpusu służby cywilnej, jeżeli wina urzędnika jest oczywista;

2) popełnienia przez urzędnika w czasie trwania stosunku pracy przestępstwa, które uniemożliwia dalsze zatrudnienie, jeżeli przestępstwo jest oczywiste lub zostało stwierdzone prawomocnym wyrokiem;

3) zawinionej przez urzędnika utraty uprawnień koniecznych do wykonywania pracy na zajmowanym stanowisku, jeżeli nie jest możliwe wyznaczenie urzędnikowi stanowiska uwzględniającego jego przygotowanie zawodowe.

W dalszej części artykułu zostaną omówione przesłanki rozwiązania stosunku pracy z urzędnikiem służby cywilnej bez wypowiedzenia z jego winy.

\footnotetext{
11 T. Liszcz, Stużba cywilna - trzecie wydanie, „Gdańskie Studia Prawnicze" 2007, t. XVII, s. 366-367.

12 Tak też M. Mazuryk, w: M. Drobny, M. Mazuryk, P. Zuzankiewicz, Ustawa o stużbie cywilnej. Komentarz, Warszawa 2012, s. 316.

${ }^{13}$ Z. Góral, Prawo pracy w samorządzie terytorialnym, Warszawa 1999, s. 142.
} 


\section{Ciężkie naruszenia przez urzędnika podstawowych obowiązków członka korpusu}

\section{służby cywilnej}

Artykuł 71 ust. 7 pkt 1 u.s.c. umożliwia rozwiązanie stosunku pracy z urzędnikiem służby cywilnej w razie ciężkiego naruszenia przez niego podstawowych obowiązków członka korpusu służby cywilnej. Obowiązki członka korpusu wymienione są w art. 76 ust. 1 pkt 1-7 u.s.c. oraz w art. 77 i 78 u.s.c. Niemniej jednak, w ustawie nie używa się sformułowania "podstawowe obowiązki", które występuje w art. 52 k.p. Może to sugerować, że obowiązki członków korpusu służby cywilnej uregulowane są także w innych aktach. Obowiązki członków korpusu służby cywilnej można podzielić na trzy rodzaje:

- dotyczące obowiązującego prawa,

- dotyczące funkcjonowania urzędu oraz

- dotyczące członków korpusu służby cywilnej ${ }^{14}$.

Urzędnik dopuszcza się ciężkiego naruszenia obowiązków, o których mowa w art. 76 u.s.c., gdy działa umyślnie i przyczynia się do zagrożenia szeroko pojętych interesów pracodawcy urzędu, przy czym jego wina musi być oczywista. Każdego z urzędników w kontekście przestrzegania przez niego obowiązków członków korpusu służby cywilnej należy oceniać indywidualnie.

Artykuł 71 ust. 7 u.s.c. daje podstawę do rozwiązania stosunku pracy z urzędnikiem służby cywilnej $\mathrm{w}$ trybie natychmiastowym $\mathrm{i} z$ jego winy. Jest to przepis, który osłabia trwałość stosunku pracy urzędnika służby cywilnej. Mimo to jest logiczną konsekwencją zawinionej utraty uprawnień koniecznych do zajmowania określonego stanowiska urzędniczego, np. szczególnych uprawnień zawodowych czy określonego rodzaju wykształcenia, czy umiejętności potwierdzonych stosownymi uprawnieniami. Przy czym zawiniona utrata uprawnień koniecznych do wykonywania pracy na zajmowanym stanowisku może być skutkiem orzeczenia sądu albo decyzji administracyjnej czy też orzeczenia komisji dyscyplinarnej ${ }^{15}$.

Zgodnie z art. 113 ust. 1 u.s.c., członek korpusu służby cywilnej odpowiada dyscyplinarnie za naruszenie obowiązków członka korpusu służby cywilnej. Ustawodawca określił, że przedmiotem postępowania dyscyplinarnego jest naruszenie przez urzędnika lub pracownika służby cywilnej obowiązków członka korpusu służby cywilnej. Niemniej jednak, pojęcie "naruszenie obowiązków członka korpusu służby cywilnej" jest pojęciem

\footnotetext{
${ }^{14}$ M. Mazuryk, Prawa i obowiazki czlonków korpusu stużby cywilnej, Księga jubileuszowa z okazji 5-lecia Wydziału Prawa Wyższej Szkoły Menedżerskiej w Legnicy, red. N. Szczęch, t. I, Legnica 2010, s. 288.

${ }^{15}$ Wyrok SN z dnia 11 grudnia 2006 r., I PK 133/06, OSNP 2008, nr 3-4, poz. 28, s. 95-99.
} 
niedookreślonym. W ustawie nie ma wskazanych wprost czynów zagrożonych odpowiedzialnością dyscyplinarną, a obowiązki członków korpusu służby cywilnej, wskazane w rozdziale 6 ustawy o służbie cywilnej, są ogólne. W związku z tym, to do pracodawcy należy ocena, czy dany czyn członka korpusu służby cywilnej lub jego zaniechanie mieści się w kategoriach naruszenia obowiązków członków korpusu służby cywilnej. Taka ocena jest później weryfikowana przez komisję dyscyplinarną ${ }^{16}$.

Zgodnie z art. 113 ust. 2 u.s.c. postępowanie dyscyplinarne nie może być wszczęte po upływie trzech miesięcy od dnia powzięcia wiadomości o naruszeniu obowiązków członka korpusu służby cywilnej. Po upływie tego terminu nie ma możliwości wszczęcia postępowania dyscyplinarnego. Podkreślenia wymaga także fakt, że w ustawie nie określono żadnych sankcji z tytułu braku wszczęcia postępowania dyscyplinarnego, co podkreśla ocenny charakter działania pracodawcy w tym zakresie.

Katalog kar, które są stosowane wobec urzędników służby cywilnej, został wymieniony w art. 114 ust. 1 u.s.c. i zalicza się do niego:

1) upomnienie,

2) naganę,

3) pozbawienie możliwości awansowania przez okres dwóch lat na wyższy stopień służbowy, 4) obniżenie wynagrodzenia zasadniczego, nie więcej niż o $25 \%$ - przez okres nie dłuższy niż sześć miesięcy,

5) obniżenie stopnia służbowego służby cywilnej,

6) wydalenie ze służby cywilnej.

Uregulowany w art. 114 ust. 1 u.s.c. katalog kar dyscyplinarnych, stosowanych wobec urzędników służby cywilnej, ma charakter zamknięty, co oznacza, że komisje dyscyplinarne nie mogą orzekać innych kar niż wskazane w tym artykule. Ponadto, katalog kar został uszeregowany od kary najmniej uciążliwej, czyli upomnienia, do kary najbardziej uciążliwej, czyli wydalenia ze służby cywilnej. Rodzaj orzeczonej przez komisję dyscyplinarną kary powinien być adekwatny do popełnionego czynu bądź zaniechania przez członka korpusu służby cywilnej.

Mając na uwadze wspomniane już regulacje, należy zastanowić się, czy przy naruszeniu obowiązków pracodawca rozwiązuje z urzędnikiem służby cywilnej stosunek pracy bez wypowiedzenia, czy wszczynane jest postępowanie dyscyplinarne. W doktrynie wskazuje się, że wprowadzenie regulacji zawartej w art. 71 ust. 7 pkt 1 u.s.c. umożliwia

\footnotetext{
${ }^{16}$ P. Zuzankiewicz, w: M. Drobny, M. Mazuryk, P. Zuzankiewicz, Ustawa o stużbie cywilnej. Komentarz, Warszawa 2012, s. 473.
} 
rozwiązanie stosunku pracy bez wypowiedzenia i bez konieczności karania urzędnika karą orzeczoną przez komisję dyscyplinarną w postaci wydalenia ze służby ${ }^{17}$. W związku z tym, że naruszenie obowiązków członka korpusu służby cywilnej jest kwestią ocenną, a w ustawie nie uregulowano katalogu czynów i zaniechań, które wypełniałyby znamiona naruszenia obowiązków, uważam, że zachowania urzędnika służby cywilnej powinny podlegać ocenie w trakcie postępowania dyscyplinarnego. Ma to szczególne znaczenie dla ochrony stosunku pracy, a także daje urzędnikowi możliwość otrzymania innej kary z katalogu wymienionego w art. 114 ust. 1 u.s.c. Wydaje się, że ustawodawca po to wprowadził katalog kar, aby dopiero za najcięższe naruszenia obowiązków urzędnika spotkało wydalenie ze służby cywilnej, a nie za każde naruszenie obowiązków.

\section{Popelnienie przez urzędnika w czasie trwania stosunku pracy przestępstwa, które uniemożliwia dalsze zatrudnienie}

Rozwiązanie stosunku pracy z urzędnikiem służby cywilnej w trybie art. 71 ust. 7 pkt 2 u.s.c. może nastąpić, gdy urzędnik służby cywilnej popełnił w czasie trwania stosunku pracy przestępstwo, które uniemożliwia dalsze zatrudnianie go na zajmowanym stanowisku, jeżeli przestępstwo to jest oczywiste lub zostało stwierdzone prawomocnym wyrokiem. W związku z tym, wspomniana regulacja nie dotyczy urzędników służby cywilnej, którzy popełnili np. wykroczenie. W doktrynie podkreśla się, że bez znaczenia pozostaje fakt, czy urzędnik popełnił przestępstwo na szkodę urzędu czy też osoby trzeciej oraz czy szkoda powstała w związku z pracą $^{18}$. Przesłanką, która decyduje o możliwości rozwiązania stosunku pracy bez wypowiedzenia $\mathrm{z}$ winy urzędnika, jest to, czy przestępstwo popełnione w czasie trwania stosunku pracy umożliwia dalsze zatrudnianie urzędnika. Sąd Najwyższy w wyroku z 31 stycznia 1977 r. ${ }^{19}$ wyraził pogląd, że przestępstwo jest oczywiste, jeżeli nienasuwający wątpliwości stan faktyczny pozwala na pewne stwierdzenie, że pracownik dopuścił się czynu zagrożonego sankcją karną przewidzianą przez ustawę. W związku z tym, nie można uznać oczywistości przestępstwa pracownika, jeśli nie ma pewności, czy przestępstwo w ogóle zostało popełnione albo kto dopuścił się popełnienia przestępstwa ${ }^{20}$. Ponadto, z uchwały Sądu Najwyższego z dnia 30 marca $1994 \mathrm{r}^{21}$ wynika, że pracodawca ma prawo samodzielnie prowadzić postępowanie wyjaśniające w tym zakresie, a postępowanie takie nie jest

\footnotetext{
${ }^{17}$ M. Mazuryk, w: M. Drobny, M. Mazuryk, P. Zuzankiewicz, Ustawa o stużbie cywilnej. Komentarz, Warszawa 2012, s. 321.

${ }^{18}$ Ibidem, s. 323.

19 I PRN 141/76, PiZS 1978, nr 4 s. 64.

20 B. Wagner, Kodeks pracy. Komentarz, Gdańsk 2004, s. 232.

${ }^{21}$ I PZP 9/94, OSNP 1994, nr 2, poz. 26.
} 
ingerencją w dobra osobiste pracownika. Warto także zaznaczyć, że stosunek pracy bez wypowiedzenia można rozwiązać $\mathrm{w}$ tym przypadku w momencie, gdy wyrok będzie prawomocny. W piśmiennictwie wskazuje się także, że jeśli w związku z popełnieniem przestępstwa urzędnik służby cywilnej zachował status urzędnika, to możliwe jest jego dalsze zatrudnienie, natomiast w przeciwnym wypadku zachodzi przesłanka uniemożliwiająca dalsze zatrudnienie urzędnika ${ }^{22}$.

\section{Zawiniona przez urzędnika utrata uprawnień koniecznych do wykonywania pracy na zajmowanym stanowisku}

Rozwiązanie stosunku pracy $\mathrm{z}$ urzędnikiem $\mathrm{z}$ jego winy bez wypowiedzenia następuje również $\mathrm{w}$ razie zawinionej przez niego utraty uprawień koniecznych do wykonywania pracy na zajmowanym stanowisku, jeżeli nie jest możliwe wyznaczenie urzędnikowi stanowiska uwzględniającego jego przygotowanie zawodowe. Dotyczy to jedynie urzędników, których praca na określonym stanowisku wymaga pewnych uprawnień. Utrata uprawnień musi wynikać $\mathrm{z}$ winy urzędnika i może być stwierdzona orzeczeniem uprawnionego organu, np. sądu. Ponadto, wskazuje się, że zawiniona utrata uprawnień koniecznych na zajmowanym stanowisku daje podstawę rozwiązania stosunku pracy dopiero wtedy, gdy nie jest możliwe wyznaczenie urzędnikowi stanowiska uwzględniającego jego przygotowanie zawodowe. Wyznaczenie takiego stanowiska, w sytuacji gdy urzędnik utracił uprawnienia, będzie zawsze uzasadnione interesem służby cywilnej ${ }^{23}$.

\section{Podsumowanie}

Rozwiązanie stosunku pracy bez wypowiedzenia $\mathrm{z}$ urzędnikiem służby cywilnej jest zagadnieniem uregulowanym w rozdziale 5 ustawy o służbie cywilnej związanym ze zmianą $i$ ustaniem stosunku pracy w służbie cywilnej. Mimo regulacji ustawowej i wymienionego katalogu sytuacji, w których następuje rozwiązanie stosunku pracy bez wypowiedzenia z urzędnikiem służby cywilnej, należy uznać, iż regulacja jest niepełna.

Po pierwsze, brakuje katalogu czynów i zaniechań, które wypełniałyby znamiona naruszenia obowiązków członka korpusu służby cywilnej. W chwili obecnej jest to sytuacja ocenna i tak naprawdę zależy od oceny pracodawcy. Wydaje się, że w lepszej sytuacji znajduje się urzędnik, wobec którego prowadzone jest postępowanie dyscyplinarne, gdyż w tej sytuacji ocena pracodawcy podlega opinii komisji dyscyplinarnej.

\footnotetext{
${ }^{22}$ Z. Góral, Prawo urzędnicze. Komentarz, red. K.W. Baran, Prawo urzędnicze. Komentarz, LEX nr 1162172.

${ }^{23}$ Z. Góral, Prawo urzędnicze..., LEX nr 1162172.
} 
Po drugie, uregulowania zawarte w art. 71 ust. 7 pkt 2 i 3 u.s.c. należy uznać jako zupełne. Zarówno popełnienie przestępstwa potwierdzone prawomocnym wyrokiem, jak i utrata uprawnień niezbędnych do wykonywania pracy na zajmowanym stanowisku są jasno sformułowane i nie budzą wątpliwości w przypadku ich zastosowania.

Reasumując, rozwiązanie stosunku pracy bez wypowiedzenia z urzędnikiem służby cywilnej jest najbardziej niekorzystną formą rozwiązania stosunku pracy dla urzędnika i znacznie osłabia ochronę stosunku pracy, którą niejako zapewnił ustawodawca dla członków korpusu służby cywilnej z uwagi na ich przygotowanie zawodowe. Ten sposób rozwiązania stosunku pracy powinien być ostatecznością i powinien dotyczyć rzeczywiście najcięższych zawinień. W pozostałych przypadkach zasadne byłoby stosowanie kar zawartych w art. 114 ust. 1 u.s.c.

\section{Bibliografia:}

\section{Literatura}

Dubowik A., Nowelizacja ustawy o pracownikach urzędów państwowych, „Praca i Zabezpieczenie Społeczne" 1995, nr 8-9

Szewczyk H., Stosunki pracy w stużbie cywilnej, Warszawa 2010,

Drobny W., Mazuryk M., Zuzankiewicz P., Ustawa o stużbie cywilnej. Komentarz, Warszawa 2012, Liszcz T., Stużba cywilna - trzecie wydanie, „Gdańskie Studia Prawnicze” 2007, t. XVII, Góral Z., Prawo pracy w samorzadzie terytorialnym, Warszawa 1999

Góral Z., w: Prawo urzędnicze. Komentarz, red. K.W. Baran, LEX nr 1162172.

Mazuryk M., Prawa i obowiązki członków korpusu stużby cywilnej, w: Księga jubileuszowa z okazji 5lecia Wydziału Prawa Wyższej Szkoty Menedżerskiej w Legnicy, red. N. Szczęch, t. I, Legnica 2010

Wagner B., Kodeks pracy. Komentarz, Gdańsk 2004,

\section{Orzecznictwo}

Wyrok TK z dnia 12 grudnia 2002 r., K 9/02, OTK 2002, nr 7 poz. 94

Wyrok SN z dnia 31 stycznia 1977 r., I PRN 141/76, „Praca i Zabezpieczenie Społeczne”1978, nr 4

Wyrok SN z dnia 11 grudnia 2006 r., I PK 133/06, OSNP 2008, nr 3-4, poz. 28

Uchwała SN z dnia 30 marca 1994 r., I PZP 9/94, OSNP 1994, nr 2, poz. 26

Wyroku SA w Poznaniu z dnia 24 kwietnia 1996 r., III AUr 42/96, „Prawo Pracy” 1997, nr 8 